\title{
CLINICAL STUDY ON THE INFLUENCE OF HYDROXYAPATITE ON APEXOGENESIS IN MONKEYS
}

\author{
PETROVIĆ VANJA*, MARKOVIĆ D*, ČAKIĆ $S^{*}$ and KRSTIĆ N** \\ *School of Dentistry, University of Belgrade, Serbia \\ ${ }^{\star}$ Faculty of Veterinary Medicine, University of Belgrade, Serbia
}

(Received 8. March 2008)

Management of the affected pulp in teeth with incomplete root formation is still an issue. Calcium hydroxide and other materials have been employed for this purpose to a greater or lesser success. Bioceramic materials are in the last decades well established in a number of different medical fields. Having its constituents the same as those of the unorganic portion of bone tissue, hydroxiapatite (HAP), one of the two forms of calcium-phosphate ceramics, is already accepted in endodontic treatment of teeth with completed root formation.

The aim of this study was to examine apexogenesis in teeth with immature roots, following the use of HAP on their affected pulp.

Examination was performed on eight young monkeys (Cercopithecus Aethiops) with incomplete root development. The $100 \mu \mathrm{m}$ synthetic HAP material was applied on 32 teeth divided into two groups of 16 teeth each. In one group teeth underwent pulpotomy, in the other high pulpotomy. Evaluation of root growth was recorded from radiographs (pre-treatment, 3 and 12 months following treatment) and by Demjrian's scale for dental maturity and tooth age determination.

On the basis of radiographic analysis, immature teeth with affected pulp treated with HAP, both with pulpotomy and high pulpotomy, reached the same stage of root development as control teeth in 50\% of cases at 3-months radiographic assesment. After 12 months all tested teeth had the same rate of root development as control teeth, except for 1 of 8 with high pulpotomy. Dentinal bridge was radiographically visible in $50 \%$ and $87.5 \%$ of pulpotomized teeth after 3 and 12 months, respectively. Neither obliteration of the root canal, presence of denticles nor the presence of deformities in the periapical region were found in any of the observed teeth.

Key words: apexogenesis, hydroxyapatite, clinical study, monkeys, radiography 


\section{INTRODUCTION}

Apexogenesis is defined as physiological completion of growth and formation of apical foramen of tooth. This term, as well, assigns therapeutic procedures on exposed, but still vital (reversibly affected) pulp of young teeth (Webber, 1984). The aim of these therapeutic procedures (pulp caping, pulpotomy, high pulpotomy) is to provide prerequisites for continued formation of the apical root (Rafter, 2005).

Due to caries or trauma the pulp may be reversibly affected, thus disturbing the physiological process of root development, and, as well interferes with the completion of the edodontic treatment of the developing tooth. Tooth injury during its development can lead to damage and functional failure of any components of the apical odontogenic complex - dental pulp, dental follicle and Hertwig's epithelial root sheath (Rafter, 2005). The potential for recovery and repair subsequent to most injuries of developing tooth, with their cellularity and vascularity of apical tissue compared to fully developed tooth, is good provided that no infection occurs (Torneck, 1982).

As a general rule, vital pulp is a necessity for dentin formation. This means that loss of vitality in permanent teeth with uncomplete formation of the apical foramen leaves a thin and weak root canal wall, which can easily be fractured (Goldberg et al., 2002). At the same time, routine endodontic techniques can not be applied due to an extremely wide root cavum with its apical portion significantly wider than its coronal portion. Non vital developing teeth are clinically treated by apexification i.e. endodontic procedure which attempts to induce apical repair by initiating a hard tissue barrier across an open apex (Yousef, 1988; Yates, 1988; Witherspoon and Ham, 2001). Prognosis for such teeth, even if succesfuly treated, is not as good as the prognosis of fully developed teeth treated by the same procedure (Metzeger et al., 2001). Therefore, in order to enable completion of root growth and development, every effort should be made to preserve the vitality of reversibly affected pulp of non mature teeth, whether the pulp cavum is exposed or not.

Apexogenesis, as a therapeutic procedure, is expected to enable the preservation of the function of Hertwig's epithelial sheat which enables root elongation until it reaches the optimal crown - root ratio, to preserve the vitality of tooth pulp whose odontoblasts are necessary to build optimal thickness of root walls, to provide the closure of the apical foramen until apical maturation, and in case of pulpotomy, to build a dentinal bridge, thus preserving pulp vitality. The success of apexogenesis overall depends on the integrity of the radicular pulp (Rafter, 2005).

The traditionally used material in the procedure of pulp and dentine covering is calcium hydroxide and closely based materials. These materials being proven useful in the immediate tretment of exposed pulp in partially developed permanent teeth (Silva et al., 2006; Accorinte et al., 2006). However, significant disadvantages of calcium hydroxide pulpotomy are the formation of a necrotic layer of pulp and subsequent pulp volume reduction (Yoshimine and Maeda, 1995) Also, human fibroblasts that come into contact with calcium hydroxide 
Acta Veterinaria (Beograd), Vol. 58. No. 4, 395-409, 2008.

Petrović Vanja et al.: Clinical study on the influence

of hydroxyapatite on apexogenesis in monkeys

show changes in both DNA and protein synthesis, and alkaline phosphatase activity (Alliot-Licht et al.,1994).

Therefore, there is a need for a material which would overcome these disadvantages. Bioceramic materials (Jean et al., 1998; Markovic et al., 2006), dentine adhesives (Hebling et al., 1999), bioactive glass materials (Shabahag et al., 2000; Salako et al., 2003) and mineraltrioxyagregate (MTA) (Schmitt et al., 2001, El Meligy and Avery, 2006) have been employed for this purpose to a greater or lesser success.

Bioceramic materials in the last decades are in use in different fields of medicine, including dentistry (Hench and Wilson, 1993). Bioactive materials are those which induce specific biological functions and formation of different connections between the tissue and the material. Calcium-phosphate ceramic is a bioactive material. It exists in a nonresorptive form - hydroxyapatite (HAP), and resorptive form - threecalciumphosphate (TCP). The constituents of HAP are the same as those of the unorganic portion of the bone tissue. Therefore, implanatation of HAP in the bone maintains the same equilibrium between calcium and phosphate on their surfaces.

The way of synthesis of HAP determines its morphology and stoichiometry. Biocompatibility of all forms of HAP is proven by numerous studies (Galgut et al., 1990; Gregoire and Menentean, 1990; Jaber et al., 1991; Markovic et al., 2004). Although fibrolasts phagocyted HAP molecules of less than $10 \mu \mathrm{m}$ which affected their DNA synthesis, its biocompatibility was not questioned because affected fibroblasts were not in the phase of differentiation (Jaber et al., 1991). The use of HAP is already widely accepted in maxillofacial and oral surgery, as well as in periodontology. HAP is also proposed as the material which could enhance the formation of the apical barier during endodontic treatment of teeth with completed root development (Daclusi et al.,1990; Jean et al., 1998; Teodorović, 2004).

HAP makes the unorganic matrix of bone tissue. The ratio between calcium and phosphate iones $(1.50-1.67)$ in synthetic HAP is similar to that of bone tissue.

HAP [Ca10 (PO4)6(OH)2] is the essential mineral component of the tooth and bone tissues. It is most stable salt at pH 7.4.

Ceramic biomaterials produced on the basis of HAP or TCP are, according to their chemical composition and structure are most similar to the unorganic component of the bone.

Besides from being biocomatible, synthetic calciumphosphate materials induce the formation of dentinal bridges. Newly calcified tissue is formed in direct contact with the material used, without formation of necrotic tissue area, which is, probably, the main disadvantage of the use of calciumhydroxyde in apexogenesis (Alliot-Licht et al., 1994).

Authors of one study on rats reported that reabsorbable material based on HAP with particles of $300-400 \mu \mathrm{m}$, not only enhance the formation of new odontoblasts and dentine bridges, but also enhance calcification in the pulp, which could interfere with endodontic treatment (Jaber et al., 1992)

The aim of this study was to examine apexogenesis in teeth with immature roots following the use of HAP. 
Petrović Vanja et al.: Clinical study on the influence of hydroxyapatite on apexogenesis in monkeys

\section{MATERIAL AND METHODS}

Tested material was synthetic HAP, Beohap, powder with particle size $100 \mu \mathrm{m}$.

Methods: The procedure was performed on vervet monkeys (Cercopithecus Aethiops). This study included eight young monkeys with minimum body weight $1500 \mathrm{gr}$, whose tooth roots were still developing. The Animal Ethical Screening Comitee permission was obtained prior to investigation. After the animals were anestethised and Rö assesment on root maturation was performed, HAP was applied on incisors, canines and premolars. The tested teeth were divided into two groups of 16 teeth each.

I - In the first group pulp was removed at the cemento-enamel junction (pulpotomy), and the wound was covered with HAP.

II - Teeth in the second group were given high amputations, with consequent wounds being covered with HAP, and their root space being obturated with obturational paste and guttapercha.

All cavities were filled with glass ionomer cement liner and amalgam fillings. Radiographs were taken three and twelve months following initial treatment.

Controls: Contralateral untreated teeth served as controls.

Monitoring and scoring: The following was monitored with the aid od radigraphs: a) presence of dentine bridges in treated teeth, b) retardation of root growth compared to controls, c) presence of canal obliteration and denticles in the newly formed part of the apex, and d) presence of pathological processes in the periapical region. The observed parameters were scored with 1 (yes) and 0 (no). The evaluation of root growth was recorded from radiographs and by Demjrian's scale for dental maturity and tooth age determination from $\mathrm{A}$ to $\mathrm{H}$ (Figure 1) (Demirjan, 1973). Root formation was considered "complete" (G,H) when the root apex was closed or near completion and the canal was tapering with near normal length. As "incomplete" (A-F) any other configuration of the root, such as shortened root with or without closed apex, closed apex with wide elliptical canal, and, of course, wide open (blunderbuss) apex was assigned.

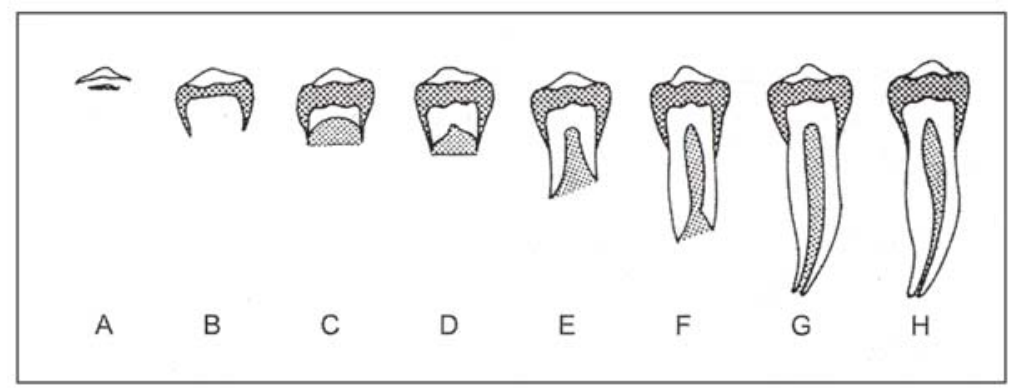

Figure 1. Demjrian's scale for dental growth and teeth mineralisation 
Acta Veterinaria (Beograd), Vol. 58. No. 4, 395-409, 2008.

Petrović Vanja et al.: Clinical study on the influence

of hydroxyapatite on apexogenesis in monkeys

\section{RESULTS}

Root formation was evaluated radiographically at 3 and 12 months intervals (Table 1 and Table 2). Dentin bridge tissue was observed in 4 teeth (50\%) in 3months-test-teeth group and in 7 teeth (87.5\%) in 12 months-test-teeth group. Root formation was delayed compared to the controls in 4 and in 1 out of 8 test teeth after 3 and 12 months respectively. Neither obliteration of the root canal and presence of denticles nor presence of deformities in the periapical region were found in any of the observed teeth.

Test teeth given pulpotomy plus HAP application in both test periods failed to show statistically signficant differences considering radiographically evaluated parameters in test and control teeth, except for the presence of dentinal bridges and for root development retardation detected both in 3 months interval (Wicoxon's test $p=0.046$ ) (Table 3). root end.

High pulpotomies were performed and Beohap was applied at the immature

On viewed radiographs root formation was slower when compared to the same parameter in control teeth in 4 out of $8(50 \%)$, and in 1 out of $8(14.3 \%)$ teeth after 3 and 12 months, respectively (Table 3, Figures 2 and 3). Deformities in the periapical region were not recorded in any of the evaluated cases. Dentinal bridges, denticles and obliteration of the root canal are considered impossible to occur in teeth given high pulpotomy (Figures 4 and 5). One test tooth in 12months-test-teeth group was excluded from the study due to filling failure (Tables 4 and 5).

Test teeth given high pulpotomy plus HAP application in both test periods failed to show statistically signficant differences considering radiographically evaluated parameters in test and control teeth, except for root development detected at 3 months interval (Wicoxon's test $p=0.046$ ) (Table 6, Figure 2).

No statistically significant difference was found considering radiographically evaluated parameters between teeth given pulpotomy and those given high pulpotomy in both test periods.

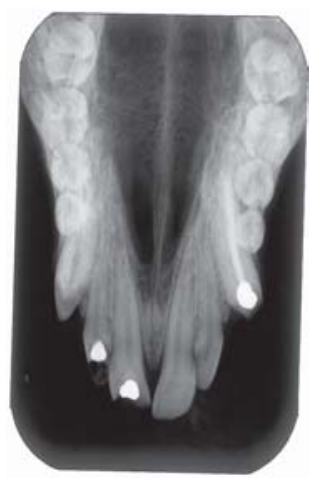

Figure 2. Maxillary right canine (high pulpotomy and HAP application), and right lateral incisor (pulpotomy and HAP application) in stage $G$ of apex formation; right central incisor (given the same treatment as lateral incisor) in stage $\mathrm{H}$ of apex formation, 3 months after treatment 
Petrović Vanja et al.: Clinical study on the influence of hydroxyapatite on apexogenesis in monkeys

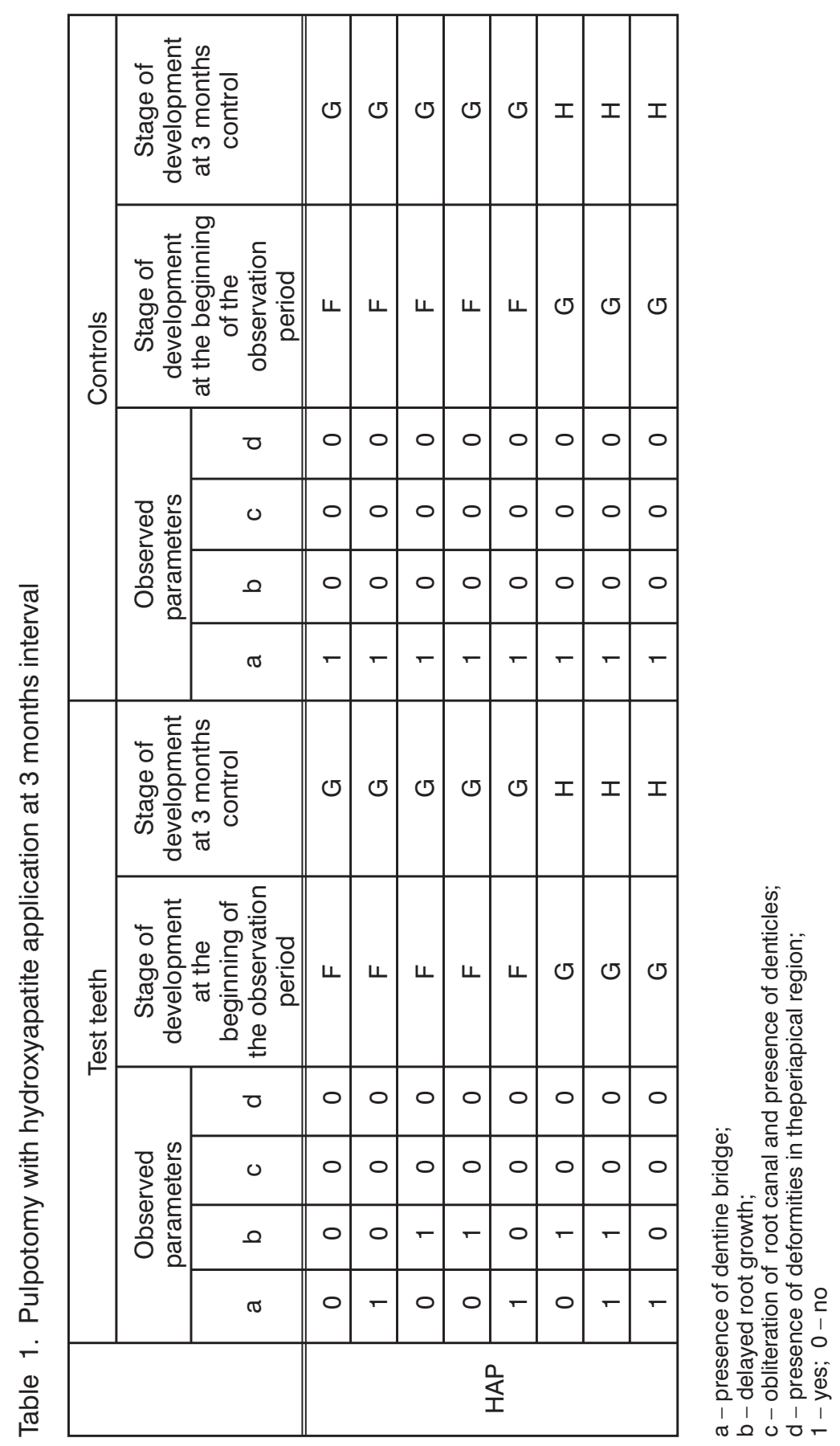


Acta Veterinaria (Beograd), Vol. 58. No. 4, 395-409, 2008.

Petrović Vanja et al.: Clinical study on the influence

of hydroxyapatite on apexogenesis in monkeys

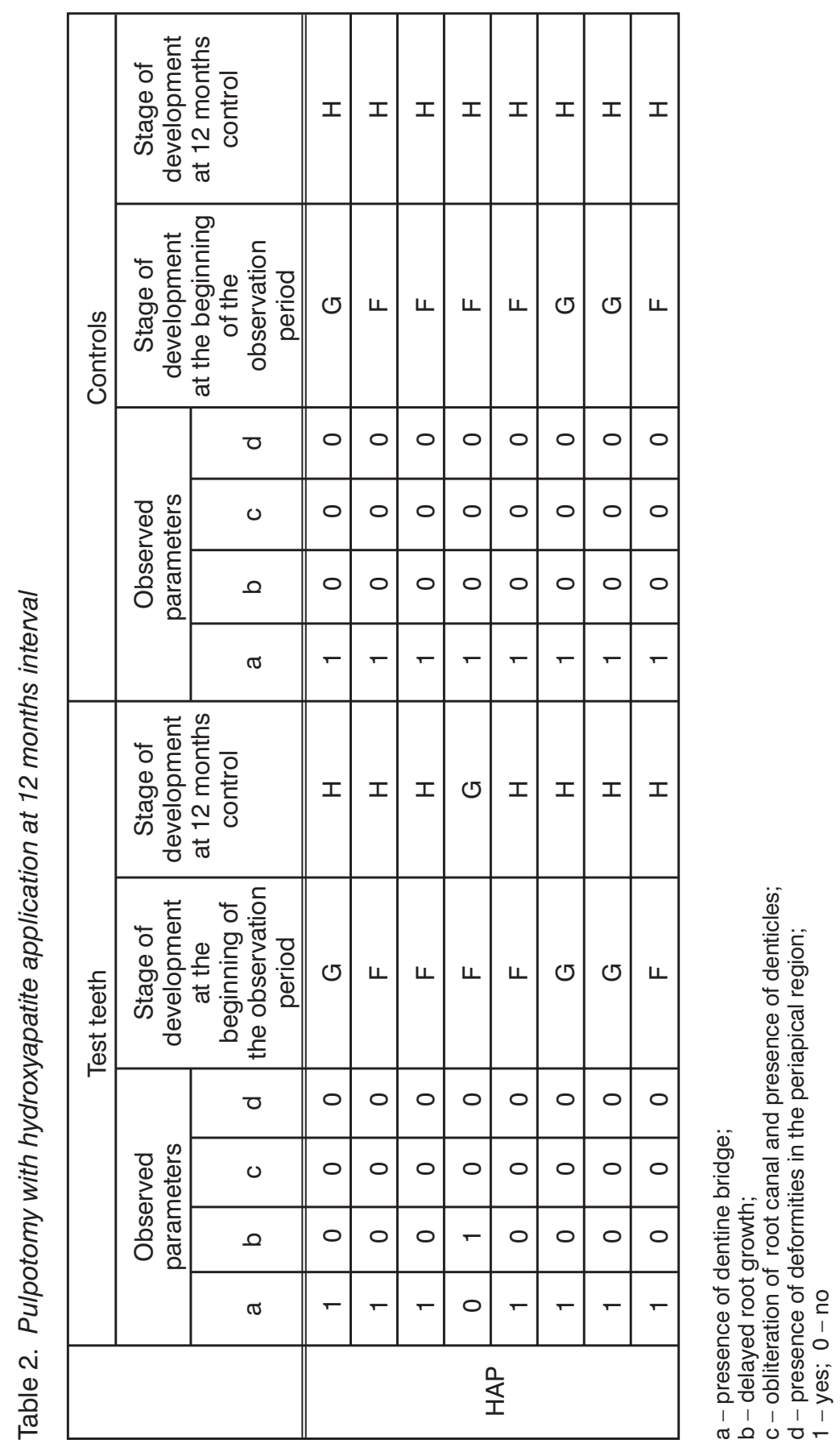



of hydroxyapatite on apexogenesis in monkeys

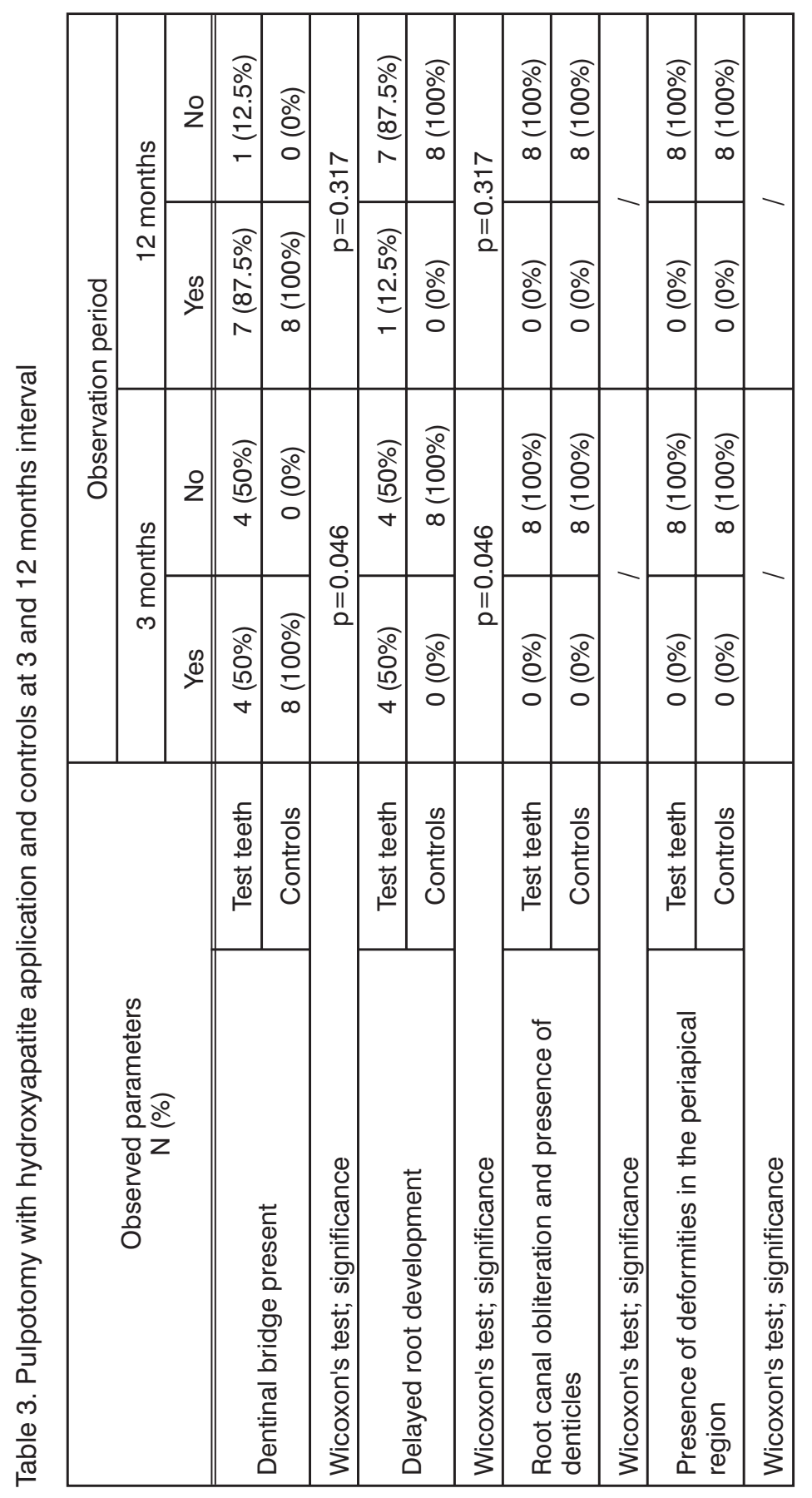


Acta Veterinaria (Beograd), Vol. 58. No. 4, 395-409, 2008.

Petrović Vanja et al.: Clinical study on the influence

of hydroxyapatite on apexogenesis in monkeys

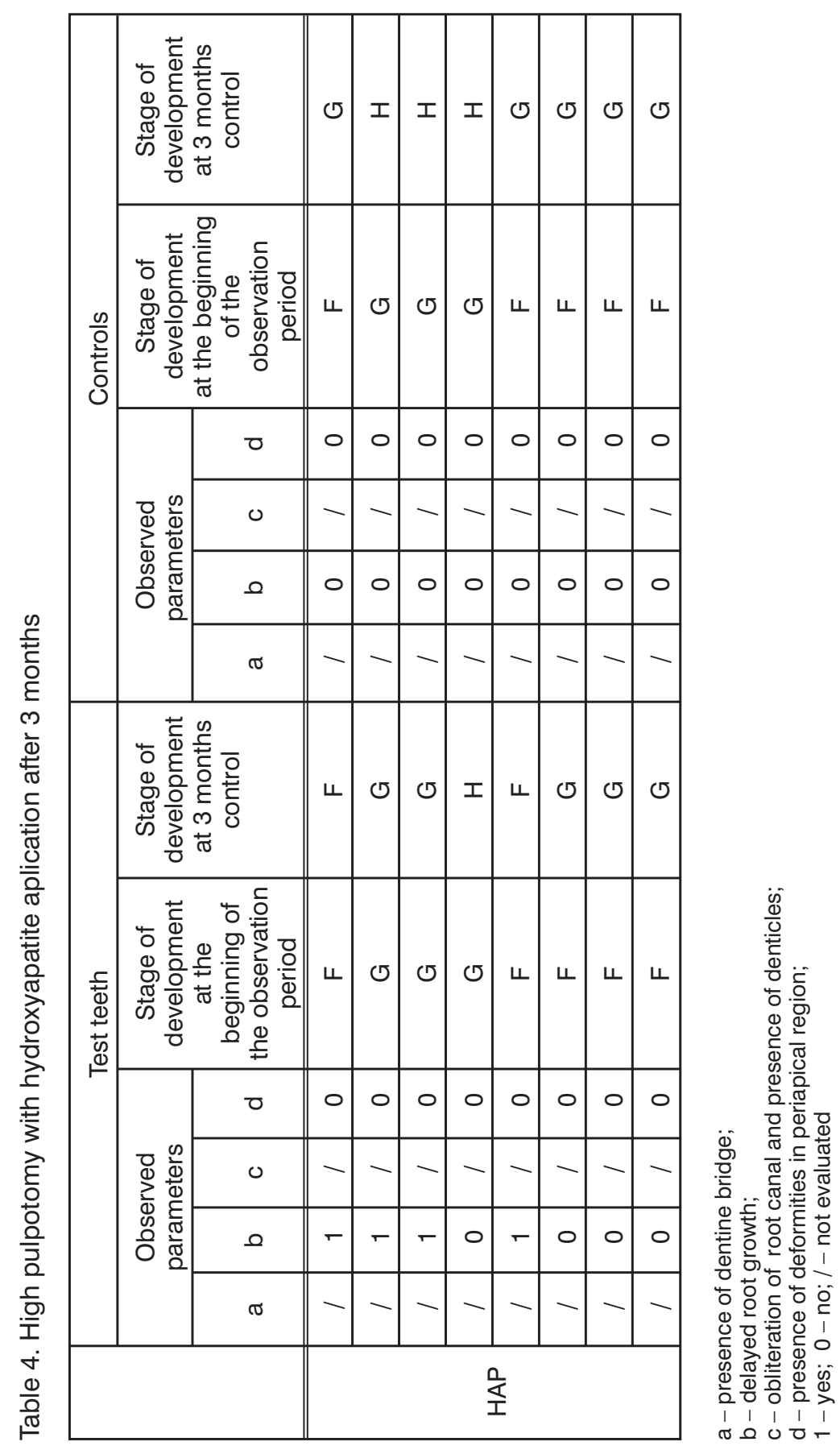


Petrović Vanja et al.: Clinical study on the influence of hydroxyapatite on apexogenesis in monkeys

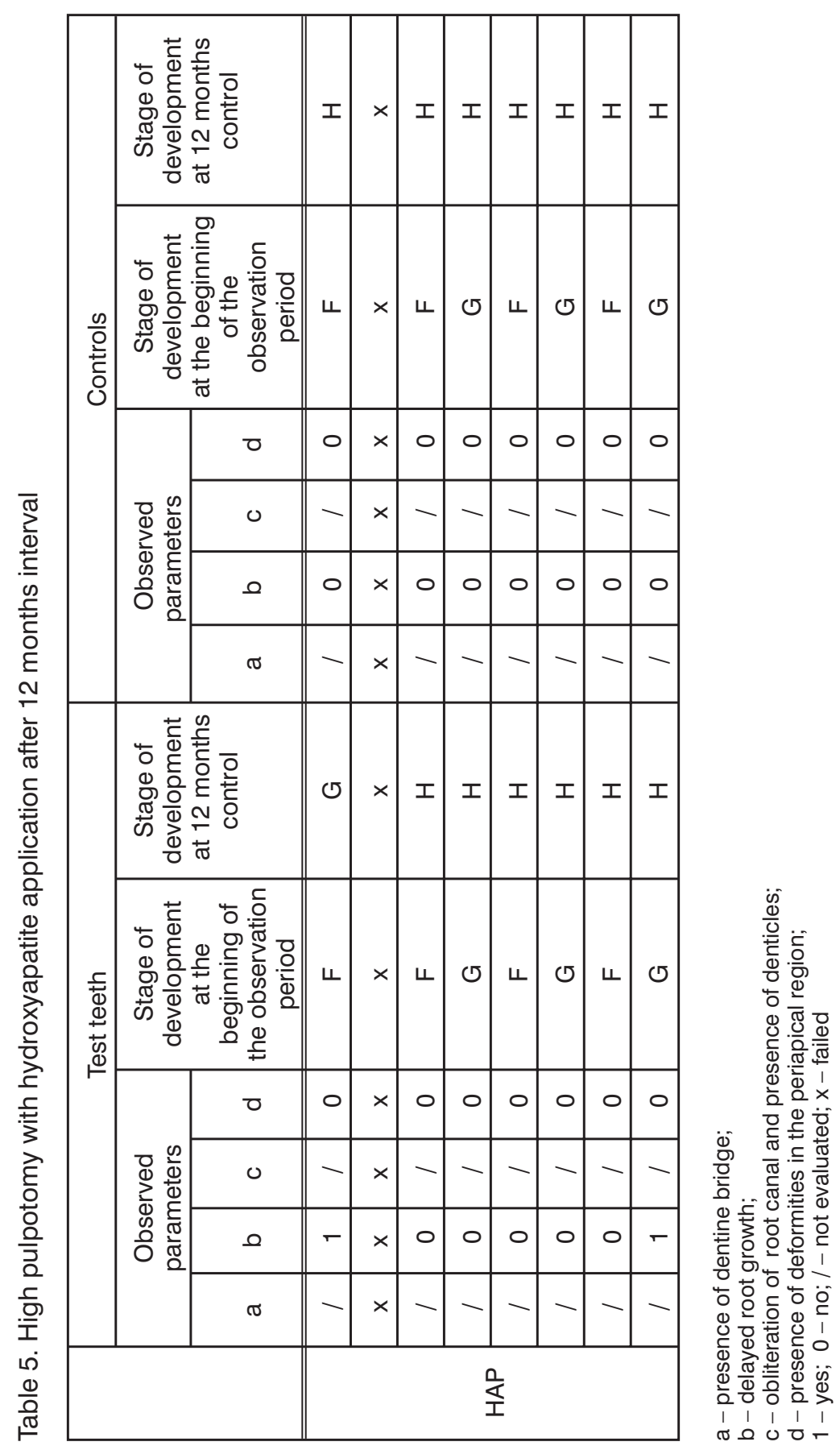


Acta Veterinaria (Beograd), Vol. 58. No. 4, 395-409, 2008.

Petrović Vanja et al.: Clinical study on the influence

of hydroxyapatite on apexogenesis in monkeys

Table 6. High pulpotomy with hydroxyapatite application and controls at 3 and 12 months interval

\begin{tabular}{|c|c|c|c|c|c|}
\hline \multirow{3}{*}{\multicolumn{2}{|c|}{$\begin{array}{l}\text { Observed parameters } \\
\text { N (\%) }\end{array}$}} & \multicolumn{4}{|c|}{ Observation period } \\
\hline & & \multicolumn{2}{|c|}{3 months } & \multicolumn{2}{|c|}{12 months } \\
\hline & & yes & no & yes & no \\
\hline \multirow{2}{*}{$\begin{array}{l}\text { Delayed root } \\
\text { development }\end{array}$} & Test teeth & $4(50 \%)$ & $4(50 \%)$ & $1(14.3 \%)$ & $6(87.5 \%)$ \\
\hline & Controls & $0(0 \%)$ & $8(100 \%)$ & $0(0 \%)$ & 7 (100\%) \\
\hline \multicolumn{2}{|c|}{ Wicoxon's test; significance } & \multicolumn{2}{|c|}{$p=0.046$} & \multicolumn{2}{|c|}{$p=0.317$} \\
\hline \multirow{2}{*}{$\begin{array}{l}\text { Presence of deformities } \\
\text { in periapical region }\end{array}$} & Test teeth & $0(0 \%)$ & 8 (100\%) & $0(0 \%)$ & $7(100 \%)$ \\
\hline & Controls & $0(0 \%)$ & 8 (100\%) & $0(0 \%)$ & $7(100 \%)$ \\
\hline \multicolumn{2}{|c|}{ Wicoxon's test; significance } & & \multicolumn{2}{|c|}{ / } \\
\hline
\end{tabular}
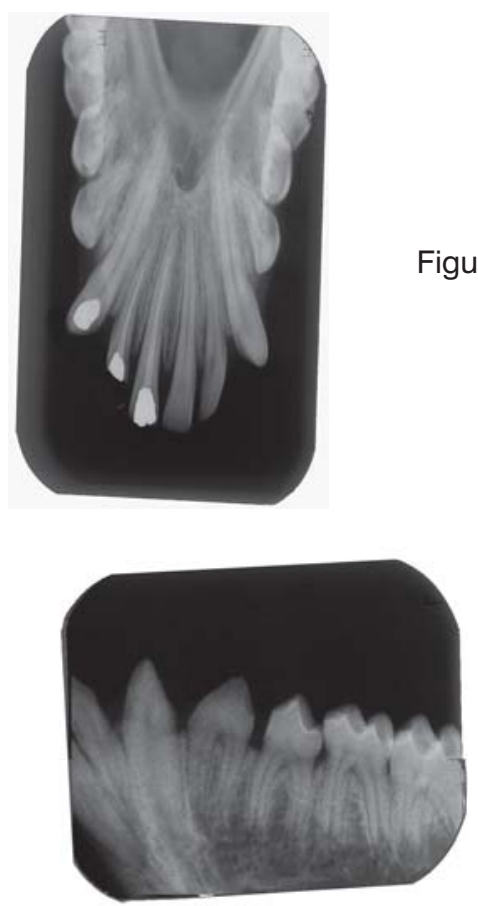

Figure 4. Pre-treatment radiography
Figure 3. Mandibular right incisors and canine (test teeth given pulpotomy and HAP application), and left incisors and canine (control teeth), both reached apex growth stage $\mathrm{H} 12$ months after initial treatment

Mandibular central incisor after high pulp amputation, HAP application, and canal obturation has reached $\mathrm{H}$ stage after 12 months interval (stage $\mathrm{G}$ pre treatment). Lateral incisor in stage G 12 months after pulp amputation and HAP application (stage $F$ pre treatment). 


\section{DISCUSSION}

Treatment of affected pulp in teeth with incomplete root formation is still a challenge due to drawbacks of traditionally used calcium hydroxide. In contact with exposed pulp $\mathrm{Ca}(\mathrm{OH})_{2}$ causes development of a heterogenous layer of dentine, which is followed by formation of tubular dentine. Jean and coworkers (Jean et al., 1992) in a microradiograph study found that the layer of reparatory dentinal tissue was thicker after appliaction of $\mathrm{Ca}$-phosphate materials than after application of $\mathrm{Ca}(\mathrm{OH})_{2}$. Some authors feature a homogene structure of dentinal bridge formed following TCP-HAP material, as well as a more rapid formation of tubulary dentine, which may implicate the shorter time required for healing of the affected pulp. Ca-phosphate materials induce the formation of dentinal reparatory bridges directly on biomaterial, without initial necrosis which occures unevitably when $\mathrm{Ca}(\mathrm{OH})_{2}$ is used (Jean et al.,1998). The presence of a solid substrate matrix, meaning the base on which pulp cells adhere and get transformed into odontoblast-like cells, is a necessity for reparatory dentinogenesis. It was found that pulp fibroblasts in the proximity of the damaged tissue induced synthesis and secretion of fibrodentinal matrix (Lesot et al., 1993). Formation of fibrodentine is considered essential as the first matrix zone, which, when mineralized, forms tubulary dentine (Tziafas et al., 2000). The area of superficial necrosis, when $\mathrm{Ca}(\mathrm{OH})_{2}$ is used, might have the same role. The role of the described matrix in reparatory dentinogenesis is probably analogue to the role of the basal membrane in the period when the tooth is in the developing phase.

HAP is a synthetic biomaterial of approved biocompatibility and bioconductivity. It's use in bone restauration and, mixed with calcium sulphate, in endodonthic treatment of teeth with completed root formation (Teodorović, 2004) is already shown to be beneficial.

Research results concerning the reaction of dental pulp to HAP and HAPinduced dentine bridge formation following pulpotomies in monkeys have been contradictory at times. However, in the same animals, when HAP was used as a direct pulp-capping agent, it failed to induce formation of complete dentinal bridges (Gregoire and Menentean, 1990). Test teeth given pulpotomy plus HAP application in both test periods of our study did not show statistically signficant differences considering radiographically evaluated parameters in test and control teeth, except for the presence of dentinal bridges and for root development retardation both detected at 3 months interval (Wicoxon's test $p=0.046$ ). Dentin bridge formation after pulpotomy and application of HAP in $50 \%$ of test teeth after 3 months and in $87.5 \%$ after 12 months was recorded. Root formation was slower than in the controls in 4 out of 8 test teeth, but only in 1 out of 8 test teeth after 12 months. In the study on pulp capping performed on monkeys (Murray et al., 2001) the dentinal bridge was, in majority of cases, formed in 97 days.

Traditionally apexogenesis involves removal of the inflamed pulp (usually the coronal portion of the pulp) and placement of medicament (calcium hydroxide or other) on the remaining healthy pulp tissue (AAPD Clinical Guidelines, 2004). The task to remove the inflamed tissue only arises the question of assessing the level of inflammation, which is determined by clinical judgment (McDonald et al., 
Acta Veterinaria (Beograd), Vol. 58. No. 4, 395-409, 2008.

Petrović Vanja et al.: Clinical study on the influence

of hydroxyapatite on apexogenesis in monkeys

2004). For this reason, the removal of pulp tissue in this study was performed at two different levels: on the level of cement-enamel junction (pulpotomy), and at the radiographically visible point of immature root (high pulpotomy). Test teeth given high pulpotomy plus HAP aplication in both test periods of our study did not show statistically signficant differences considering radiographically evaluated parameters in test and control teeth, except for root development retardation detected in 3 months interval (Wicoxon's test $p=0.046$ ). No statistically significant difference was found considering radiographically evaluated parameters between teeth given pulpotomy and those given high pulpotomy in both test periods in our study.

In order to study the osteogenic action of HAP on dental pulp, direct pulp capping was performed in rats. Globular dentine tissue of irregular distribution was observed 4 weeks after treatment. However, examined material (Osteogen $₫$ ) was not recommended for pulp capping in humans due to formation of areas of calcification that would seriously interfere with potential endodontic treatment. (Jaber et al., 1992). In the clinical study performed in 30-day and 60-day intervals on premolars indicated for extraction due to orthodontic reasons, no firm tissue barrier was formed in teeth treated with HAP, but it was formed on teeth treated with Dycal ${ }^{\circledR}$ (calciumhydroxide material) (Subay and Asci, 1993). Authors suggest further studies on the use of calcium hydroxide in the treatment of affected pulp, particularly in combination with collagen. Few years earlier (Jean et al., 1988) study conducted on deciduous pig teeth in the conclusion gives preference to HAP and TCP over $\mathrm{Ca}(\mathrm{OH})_{2}$ due to earlier and more regular formation of reparatory dentine. No denticles and root canal obliterations were detected in any of radiographically evaluated teeth in our study.

Apexogenesis on test teeth (young permanent teeth with affected pulp) in our study continued in much the same way as in the untreated control teeth, which makes results of our study on the use of HAP in apexogenesis promising.

ACKNOWLEDGEMENTS:

The Ministry of Science and Technology, Republic of Serbia, Project Grant No. 145042, supported this research.

Address for correspondence:

Petrović Vanja:

Clinic of Preventive and Pediatric Dentistry,

School of Dentistry,

University of Belgrade,

Dr Subotića street 11,

11000 Belgrade, Serbia

E-mail: vanja65@hotmail.com

\section{REFERENCES}

1. Accorinte MLR, Reis A, Loguercio AD, Araujo VC, Muench A, 2006, Influence of rubber dam isolation on human pulp responses after capping with calcium hydroxide and adhesive system, Quint Int, 37, 3, 205-12. 
2. Alliot-Licht B, Jean A, M.Gregoire $M, 1994$, Comparative effect of calcium hydroxide and hydroxyapatite on the cellular activity of human pulp fibroblasts in vitro, Archs Oral Biol, 39, 6, 481-9.

3. American Academy of Pediatric Dentistry, 2004, Clinical guideline on pulp therapy for primary and young permanent teeth, Reference Manua, 12-5.

4. Daculsi K, Legeros RZ, Deudon C, 1990, formation of carbonate-apatite crystals after implantation of calcium phosphate ceramics, Calcif Tissue Int, 24, 471-88.

5. Demirijan A, Buschang PH, Tangay R, Kingnorth PD, 1985, Interrelationships among measures of somatic, sceletal, dental and sexual matrity, Am J Orthod, 88, 433-8.

6. El Meligy OAS, Avery DR, 2006, Comparison of apexification with mineral trioxide aggregate and calcium hydroxide, Ped Dent, 28, 3-5.

7. Galgut PN, Waite JM, Tinkler SMB, 1990, Histopathological investigation of the tissue response to hydroxyapatite used as an implant material in periodontal treatment, Clin Mater, 6, 105-21

8. Goldberg F, Kaplan A, Roitman M, Manfre S, Picca M, 2002, Reinforcing effect of a resin glassionomer in the restoration of immature roots, Dent Traumat, 18, 70-2

9. Gregoire M, Menantean O, 1990, The influence of calcium phosphate biomaterials on human bone cell activities: an in vitro approach, $J$ Biomed Mat Res, 24, 163-77.

10. Hebling J, Aaprecida Giro EMD, Souza Costa C, 1999, Biocompatibility of an adhesive system applied to exposed human dental pulp, J Endod , 25, 112-20.

11. Jabber L, Mascres C, Donohue WB, 1991, Electron microscope characteristics of dentin repair after hydroxyapatite direct pulp capping in rats, J Oral Pathol Med, 20, 502-8.

12. Jabber L, Mascres C, Donohue WB, 1992, Reaction of the dental pulp to hydroxyapatite, Oral Surg Oral Med Oral Pathol, 73, 92-8.

13. Jean A, Kerebel B, Kerebel LM, Legeros RZ, Hamel H, 1998, Effects of Various calcium phosphate biomaterials on reparative dentin bridge formation, $J$ Endod, 2, 14-5.

14. Lesot H, Begue-Kirn C, Kubler JD, Meyer JM, Smith AJ, Cassidy N et al, 1993, Experimental induction of odontoblast differentiation and stimulation during reparative processes, Cells Mater, 3, 201-17.

15. Markovic D, Zivojinović V, Jokanovic V, Krstic V, 2006, Biocompatibility of nanostructured carbonated calcium hidroxyapatite obtained by hidrothermal method, Acta Vet, 56, 5-6.

16. Markovic D, Zivojinović V, Kokovic V, Jokanovic V, 2004, Hydroxyapatite as the root canal system filling material: a cytotoxicity testing, Mat Sci Forum, 453, 555-61.

17. Mc Donald RE, Avery DR, Dean J, 1993, An introduction to bioceramic, In: Mc Donald RE, Avery DR, Dean J, editors, Advanced series in ceramics, Vol I, Daytona Beach, World Scientific Publishing Co, 2-4.

18. Mc Donald RE, Stookey GK, Avery DR, 2004, Treatment of deep caries, vital exposure and pulpless teeth, In: Mc Donald RE, Avery DR, editors, Dentistry of the child and adolescent, St. Luis: Mosby, Eighth edition, 219-39.

19. Metzeger Z, Solomonov M, Mass E, 2001, Calcium hydroxide retention in wide root canals with flaring apices, Dent Traumat, 17, 86-92

20. Murray PE, Hafez AA, Smith AJ, Cox CF, 2001, Hierarchy of pulp capping and repair activities responsible for dentin bridge formation, $A m J$ Dent, 22, 230-8.

21. Rafter M, 2005, Apexification: a review, Dent Traumat, 21, 1-8.

22. Salako N, Joseph B, Ritwik P, Salonen J, John P, Junaid TA, 2003, Comparison of bioactive glass, mineral trioxide aggregate, ferric sulfate, and formocresol as pulpotomy agents in rat molar, Dent Traumat, 19, 314-20.

23. Schmitt D, Lee J, Bogen G, 2001, Multifaceted use of ProRoot MTA root canal repair material, Pediatr Dent, 23, 326-30.

24. Shabahang S, Torabinejad M, 2000, Treatment of teeth with open apices using mineral trioxide aggregate, Pract Periodont Aesthet Dent, 12, 3, 315-20.

25. Silva AF, Tarquino FF, Demarco FF, Piva E, Rivero ERC, 2006, The influence of haemostatic agents on healing of healthy human dental pulp tissue capped with calcium hydroxide, Int End Jour, 39, 309-16. 
Acta Veterinaria (Beograd), Vol. 58. No. 4, 395-409, 2008.

26. Subay RK, Asci S, 1993, Human pulpal response to hydroxyapatite and a calcium hydroxide material as direct capping agents, Oral Surg Oral Med Oral Pathol, 76, 4.

27. Teodorovic N, 2004, Keramički materijali na bazi hidroksiapatita u endodontskoj terapiji kanala korena zuba, Monografija, Stomatološki fakultet u Beogradu, 24-4.

28. Torneck $C D, 1982$, Effects and clinical significance of trauma to the developing permanent dentition, Dent Clinf North Am, 3, 26-31.

29. Tziafas $D$, Smith AJ, Lessot $H, 2000$, Designing new treatment strategies in vital pulp therapy, $J$ Dent, 28, 77-92.

30. Webber RT, 1984, Apexogenesis versus apexification, Dent Clin N Am, 8, 4-18.

31. Witherspoon DE, Ham K, 2001, One-visit apexification, technique for inducing root-end barrier formation in apical closures, Pract Proceed Aesthet Dent, 13, 6, 455-60.

32. Yates JA, 1988, Barrier formation time in non-vital teeth with open apices, Int Endod Jour, 21, 313-9.

33. Yoshimine Y, Maeda K, 1995, Histologic evaluation of tetracalcium phosphate-based cement as a direct pulp-capping agent, Oral Surg, Oral Med, Oral Path, 79, 3, 351-8.

34. Yousef Saad A, 1988, Calcium xydroxide and apexogenesis, Oral Surg, Oral Med, Oral Pathol, 66, 499-501.

UTICAJ HIDROKSIAPATITA NA APEKSOGENEZU U MAJMUNA: KLINIČKA STUDIJA

\author{
PETROVIĆ VANJA, MARKOVIĆ D, ČAKIĆ S i KRSTIĆ N
}

\title{
SADRŽAJ
}

Lečenja aficirane pulpe zuba sa nezavršenim rastom korena je još uvek predmet stručnih i naučnih rasprava, između ostalog i zbog neželjenih efekata tradicionalnih preparata na bazi kalcijum hidroksida. Biokeramički materijali se već nekoliko decenija primenjuju u različitim granama medicine, a hidroksiapatit, kao jedna od dve forme kalcijum-fosfatne keramike, ima gotovo istovetan sastav kao neorganski deo kosti, pa je već prihvaćen u endodontskom lečenju zuba sa završenim rastom korena. Cilj ovog rada je bio da se ispita uticaj hidroksiapatita na apeksogenezu u zuba sa nezavršenim rastom korena i aficiranom pulpom.

Ispitivanjem je bilo obuhvaćeno na osam mladih majmuna Cercopithecus Aethiops sa nezavršenim rastom korena zuba. Sintetički hidroksiapatit, veličine čestica od $100 \mu \mathrm{m}$ je primenjen na trideset dva zuba, podeljenih u dve jednake grupe kod kojih je všena apulpotomija, odnosno visoka pulpotomija. Rendgenološka evaluacija rasta korena zuba je vršena pre terapije, kao i tri i dvanaest mesici posle primene HAP, a na osnovu Demjrianove skale za određivanje zrelosti zuba.

$\mathrm{Na}$ osnovu rendgenološke analize posle 3 meseca je nađeno da je brzina razvoja korena kako pulpotomisanih, tako i visoko pulpotomisanih zuba kod kojih je primenjen HAP bila u 50\% slučajeva ista kao kod kontrolnih zuba. Posle 12 meseci stepen razvoja korena zuba je u svih ispitivanih zuba (osim kod jednog od osam zuba sa izvršenom visokom pulpotomijom) bio isti kao u kontrolnih zuba. Dentinski most je bio vidljiv radiološkom analizom u $50 \%$ odnosno $87,5 \%$ eksperimentalnih zuba posle 3, odnosno posle 12 meseci. Ni u jednom pregledanom zubu rendgenološki nije uočena obliteracija kanala korena, kao ni dentikli ni deformiteti u periapeksnom predelu. 